\title{
An Investigation on the Surface Austempering of Ductile Cast Iron
}

\author{
(Kajian terhadap Permukaan Austempering Besi Tuang Mulur)
}

Abdolali Fayyaz*, Nasser Varahram \& Parviz Davami

\begin{abstract}
This research presents surface austempering of ductile cast iron. Surface of pearlitic ductile cast iron samples were austenitised and heated to 810 and $850^{\circ} \mathrm{C}$ and held at these temperatures for 90 and $105 \mathrm{sec}$ and then austempered at a temperature of $325^{\circ} \mathrm{C}$ for 60 and $90 \mathrm{~min}$. The microstructure of samples was evaluated by optical microscopy. The hardness profile in polished cross section was also determined. In addition, the depth of austmpered layer was measured. The result indicated that temperature and time of austenitisation intensely effect on surface austempering process. The test results also revealed that the hardness of austempered layer increase when the austenitising temperature and time increase. After surface austempering of ductile cast iron samples, the highest hardness achieved $450 \mathrm{HV}$ in austempered surface-layer. The highest depth of austempered layer $1.7 \mathrm{~mm}$ was obtained.
\end{abstract}

Keywords: Austempered ductile iron; Surface hardening; Hardness; Microstructure; Austenitisation

\section{INTRODUCTION}

Austempered ductile iron (ADI) has found vast applications in different industries recent years. ADI presents high strength combined with suitable toughness. Today, it is an alternative of forged and heat treated steel with lower cost. ADI has been marked potential for numerous applications in heavy, automotive, constraction and farming industry due to indicate superior mechanical properties such as good fatigue resistance, high hardness with good ductility and good wear resistance properties (Aranzabal et al. 1997; Zhang et al. 2004; Cakir et al. 2005; Arun \& Sandeep 2016, Larumbe et al. 2017).

Today, many investigations performed to study and improve surface properties of metal and alloys components such as corrosion, wear and fatigue of different materials (Asif et al. 2001; Ghazali 2006; Sahasrabudhe et al. 2016). Surface hardening or case hardening is an useful process for modification of surface layer properties. Several methods have been made to harden the surface of the components to increase mechanical properties on surface layer without tranformation on core of components. Different methods have been used to heat surface area of ductile cast iron such as induction, flame, laser and electron contact hardening before quenching and tempered to obtain a surface layer with high hardness and good wear resistance properties (Kchaou et al. 2010; Qi et al. 2014; Fischer et al. 2014). Tempered martensitic matrix may be developed for wear resistance, but lack the toughness and ductility of either austempered ductile cast iron.

Surface austempering of ductile cast iron, also called selective austempering is a suitable method of producing austempered layer in selective area of a parts. The ADI microstructure form in surface layers of components. It is only gived combination of hardness, strength, and wear resistane in the area where it is required, while other sections of component remain pearlitic microstructure (Hornung 1986).
Surface austempering have excellent metallurgical properties, but insufficient reported about this heat treatment method. Selective hardening for the production of partial austempered cast iron components was inestigated by Kovacs and Keough (1993). They demonstrated this method has the potential for production parts with reasonable mechanical properties in selective austempered area. There are no scientifice report that study the details of surface austempering process and its parameters.

This paper is concerned with a more detailed study of the surface austempering of ductile cast iron. The effect of austenitisation temperature and time on the microstructure and the austmpered layer were investigated.

\section{METHODOLOGY}

A pearlitic ductile cast iron (GGG-70) was the raw material used in this work. The raw material was supplied by Luleh Va Mashinsazi Iran Co., Iran. In this study, the chemical composition measurement of the ductile cast iron was conducted with an atomic emmision spectroscopy analyser. The chemical composition was presented in Table 1. The materials were cast in Y-block shape, which were made by melting the sorel iron ingot, scrap iron, ferrosilicon and ferromanganese in the induction furnace, with spheroidizing $\mathrm{NiMg}$ alloy using the sandwich method. The cylinder shap samples were cut from the bottom section of Y-block, which had a length of $35 \mathrm{~mm}$ and diameter of $13.5 \mathrm{~mm}$.

TABLE 1. Chemical composition (wt.\%) of pearlitic ductile cast iron as cast

\begin{tabular}{ccccccc}
\hline $\mathrm{C}$ & $\mathrm{Si}$ & $\mathrm{Mn}$ & $\mathrm{Ni}$ & $\mathrm{S}$ & $\mathrm{P}$ & $\mathrm{Mg}$ \\
\hline 3.351 & 2.534 & 0.036 & 0.072 & 0.01 & 0.025 & 0.056 \\
\hline
\end{tabular}


The surface of ductile cast iron sample was heated to austenitising temperature 810 and $850^{\circ} \mathrm{C}$ by immersing sample in molten $\mathrm{Al}-12 \% \mathrm{Si}$ bath for 90 and $105 \mathrm{sec}$. The austenite layer was created on surface of sample, without considerable changing in core temperature of sample.

Afterwards, the sample transfer to molten salt bath at austempering temperature $325^{\circ} \mathrm{C}$ for 60 and 90 min untile austempering transformation performed on surface of sample.

The microstructure of sample was evaluated by optical microscopy and color etching to detect different phases in microstructure (Kovacs 1987). The hardness of as-cast ductile iron and austempered ductile cast iron was measured by macro Vickers hardness meter with a load of $40 \mathrm{~kg}$ and micro Vickers hardness teseter with a load of $100 \mathrm{~g}$. The hardness distribution in polished cross section was also analysed. In addition, the depth of layer of austmpering also was measured.

\section{RESULTS AND DISCUSSION}

Figure 1 shows the hardness profile along the sample cross section that austenitised at $810^{\circ} \mathrm{C}$ for 90 and $105 \mathrm{sec}$ and austempered at $325^{\circ} \mathrm{C}$ for $60 \mathrm{~min}$. The hardness value increase from $295 \mathrm{HV}$ to $410 \mathrm{HV}$ along the cross section in austempered sample at $325^{\circ} \mathrm{C}$ for $60 \mathrm{~min}$. The hardness value also increase from interior of the sample to surface layer after austempering at $325^{\circ} \mathrm{C}$ for $90 \mathrm{~min}$, from $320 \mathrm{HV}$ to $395 \mathrm{HV}$. Figure 2 shows the hardness profile along the sample cross section that austenitised at $810^{\circ} \mathrm{C}$ for 90 and $105 \mathrm{sec}$ and austempered at $325^{\circ} \mathrm{C}$ for $90 \mathrm{~min}$. It shows that the heat-treated surface layer of the sample is hardened. The austempering microstructure also formed, and the core of the ductile cast iron sample remains almost unheated and near the as-cast ductile iron hardness $(272 \mathrm{HV})$. The surface hardness values of the sample was obtained, which is comparable with hardness that was reported in previous studies for ADI structure (Aranzabal

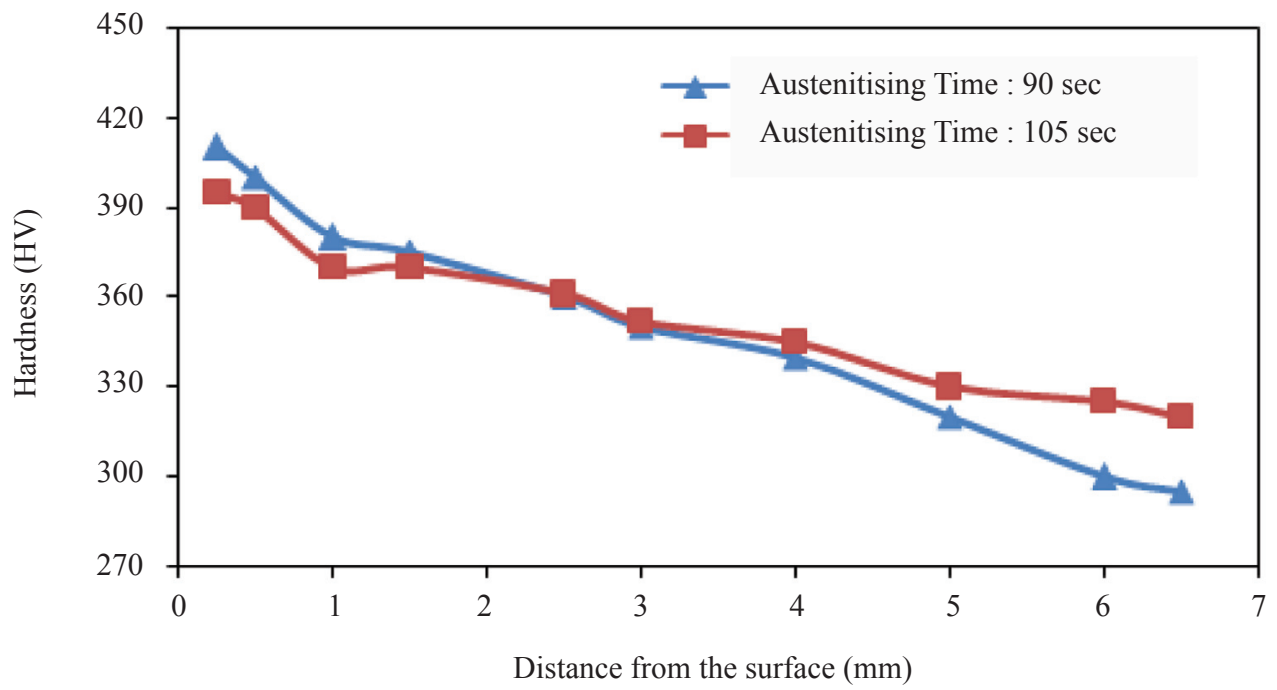

FIGURE 1. Relation between distance from surface and hardness of austenitisd at $810^{\circ} \mathrm{C}$ for 90 and $105 \mathrm{sec}$ and austempered at $325^{\circ} \mathrm{C}$ for $60 \mathrm{~min}$

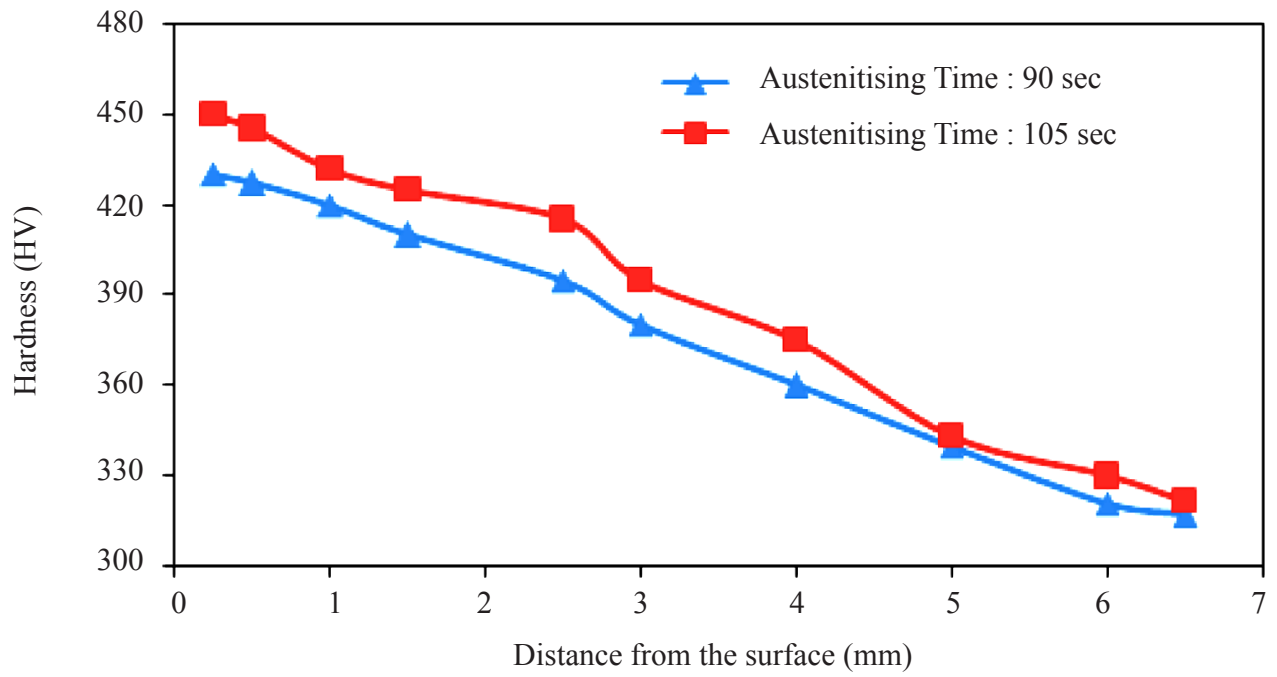

FIGURE 2. Relation between distance from surface and hardness of austenitised at $850^{\circ} \mathrm{C}$ for 90 and $105 \mathrm{sec}$ and austempered at $325^{\circ} \mathrm{C}$ for $90 \mathrm{~min}$ 
et al. 1997). As the austenitising temperature increases, the hardness on the surface layer increases, due to increasing austenitising temperature speed up the austenitisation kinetics and austempering transformation (Darwish \& Elliott 1993).

The depth of ADI layer was obtained by measuring distance between the point of maximum hardness value and the point of $90 \%$ of maximum hardness value. The surface austempering depth is presented in Table 2. Austempered thickness layer increases as the austenitising time increases. As can be seen in Table 2, the austenitising time more effect on austempering depth than austempering time. The austenitising time is the main parameter affect on the surface hardening depth. This may be attributed to forming more austenite phase in longer time of austenitisation.

TABLE 2. Surface austempering depth

\begin{tabular}{ccccc}
\hline $\begin{array}{c}\text { Austenitising } \\
\text { temperature }\left({ }^{\circ} \mathrm{C}\right)\end{array}$ & $\begin{array}{c}\text { Austenitising } \\
\text { time }(\mathrm{sec})\end{array}$ & $\begin{array}{c}\text { Austempering } \\
\text { temperature }\left({ }^{\circ} \mathrm{C}\right)\end{array}$ & $\begin{array}{c}\text { Austempering } \\
\text { time }(\mathrm{min})\end{array}$ & $\begin{array}{c}\text { Austempering } \\
\text { depth }(\mathrm{mm})\end{array}$ \\
\hline 810 & 90 & 325 & 60 & 0.83 \\
810 & 90 & 325 & 90 & 0.95 \\
810 & 105 & 325 & 60 & 1.63 \\
810 & 105 & 325 & 90 & 1.35 \\
850 & 90 & 325 & 60 & 1.40 \\
850 & 90 & 325 & 90 & 1.45 \\
850 & 105 & 325 & 60 & 1.65 \\
850 & 105 & 325 & 90 & 1.70 \\
\hline
\end{tabular}

The as-cast ductile iron microstructure is indicated in Figure 3 . The fully pearlitic microstructure of ductile iron is seen in the micrograph of Figure 3. This figure indicates clear the alternate planes of ferrite and cementite and large graphite nodule (arrow).

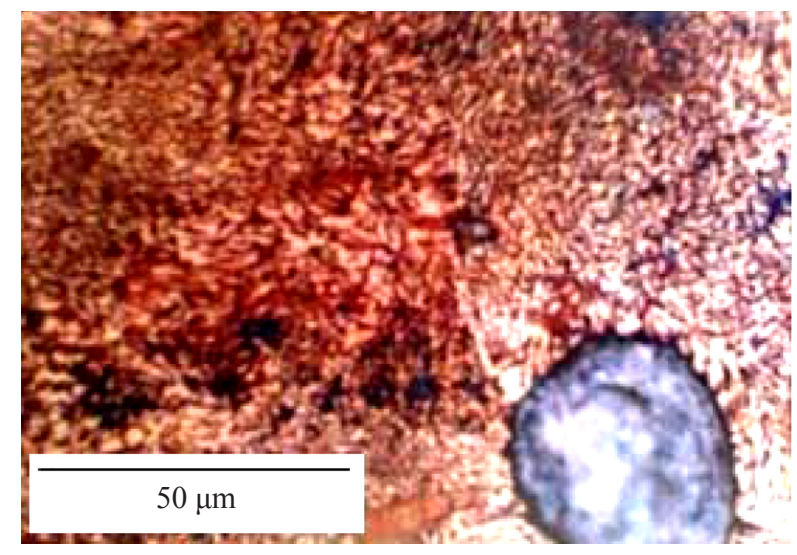

FIGURE 3. Color etching and microstructure of a-cast ductile iron

Figure 4(a) and (b) indicate microstructure of surface and interior of austempered sample. While the austenitised layer sample was held at the austempering temperature, needle-shaped ferrite was formed and grew, accompanied by rejection of carbon into the austenite. After isothermal heat treatment, the ADI microstructure was seen mostly on the surface of sample in Figure 4(a). The matrix consist of very fine needle-shaped ferrite (blue and brown) and retained austenite (white), described as ausferrite which is also called as bainite. The color etching was used for eventual separation of martensite and bainite. As seen in Figure 4(a), few martensite phases (dark blue) was observed in matrix, but identification is so difficult. The size and shape of graphitic nodules in the samples after surface austempering were not changed in comparison with the as-cast samples. Figure 4(b) shows a interior microstructure of surface austempered sample. This figure indicate, the core of sample are not changed considerably and remain mostly pearlitic microstructure. The graphitic nodules is seen in same shape and size.

\section{CONCLUSION}

This study presents an investigation of surface austempering of ductile cast iron. The findings point out that as-cast ductile iron with pearlitic microstructure could be successfully austempered on surface using the molten Al-12\% $\mathrm{Si}$ as austenitised bath. Hardness distribution in polished cross section of sample indicates phase transformation during surface austempering of ductile cast iron. The hardness of the surface ADI layer was reasonable high in comparison with the hardness of conventional austempered ductile iron structure. The austempered microstructure shows in surfacelayer an acicular bainitic ferrite and retained austenite and graphitic nodules dispersed in matrix without tranformation on core of samples. 

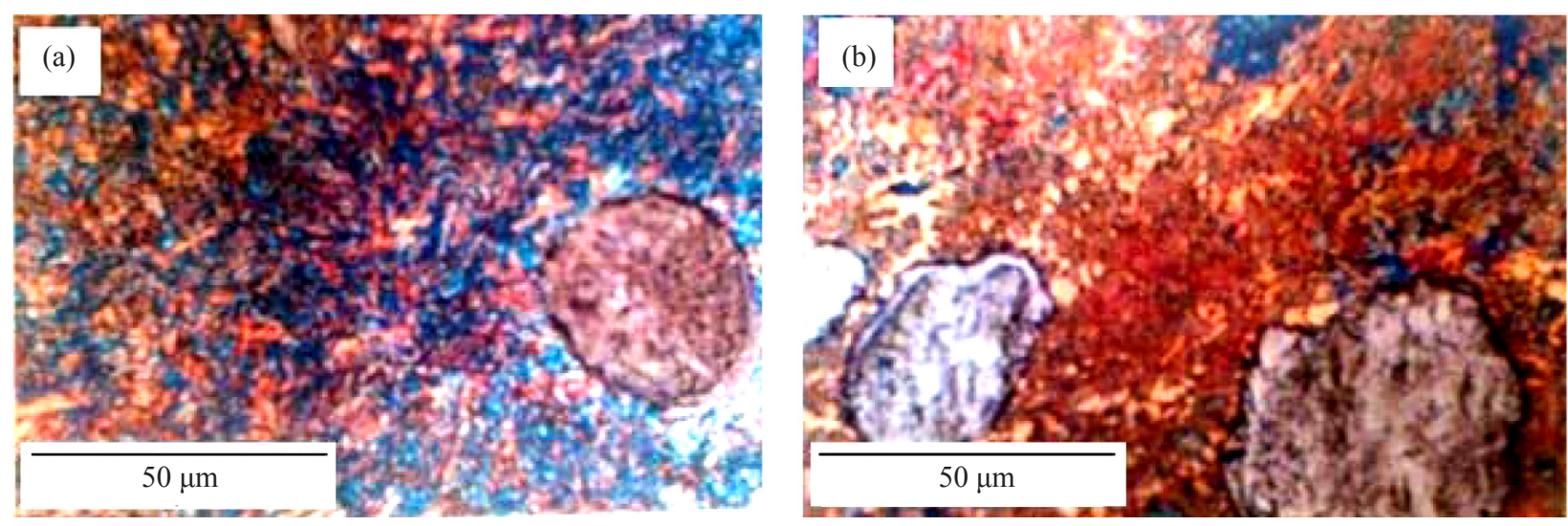

FIGURE 4. Color etching and microstructure of surface austempered sample (a) surface layer, (b) interior

ACKNOWLEDGEMENTS

The authors wish to express their gratitude to Sharif University of Technology, Luleh Va Mashinsazi Iran Co. (Mr. Maghsodi) and Foulad Rizan Co. (Mr. Kafaee) for providing raw materials, equipments and testing instruments.

\section{REFERENCES}

Aranzabal, J., Gutierrez, I., Rodriguez-Ibabe, J. M. \& Urcola, J. J. 1997. Influence of the amount and morphology of retained austenite on the mechanical properties of an austempered ductile iron. Metallurgical and Materials Transactions A 28(5): 1143-1156.

Arun V. K. \& Sandeep K. A. 2016. Characterization and sliding wear analysis of austempered ductile iron. International Journal of Materials Science and Engineering 4(1): 1-15.

Asif, S. A. S., Colton, R. J. \& Wahl, J. K. 2001. Nanoscale surface mechanical property measurements: force modulation techniques applied to nanoindentation. $A C S$ Symposium Series 781: 198-215.

Cakir, M. C., Bayram, A., Isik, Y. \& Salar, B. 2005. The effects of austempering temperature and time onto the machinability of austempered ductile iron. Materials Science and Engineering A 407(1-2): 147-153.

Darwish, N. \& Elliott, R. 1993. Austempering of low manganese ductile irons. Materials Science and Technology 9(7): 586-602.

Fischer, S. F., Muschna, S. \& Bührig-Polaczek, A. 2014. In-situ surface hardening of cast iron by surface layer metallurgy. Materials Science and Engineering A 615: 61-69.

Ghazali, M. J. 2006. Wear characteristic of several commercial wrought aluminium alloys against tool steel. Jurnal Kejuruteraan 18: 49-56.

Hornung, K. 1986. Techniques for austempering ductile iron. Heat Treatment of Metals 13(4): 87-94.

Kchaou, M., Durand, D. \& Dammak, F. 2010. Superficial quenching of mechanical pieces and calculation of residual stresses: modeling and simulation. Metal Science and Heat Treatment 52(3-4): 157-162.
Kovacs, B. V. \& Keough, J. R. 1993. Method for producing a selectively surface hardened cast iron part. US Patent $5,246,510$.

Kovacs, B. V. 1987. A Simple Technique to Identify Various Phases in ADI. Modern Castings 77(6): 34-35.

Larumbe, L. H., Delgado, E.H., Alvarez-Vera, M. \& Villanueva, P. P. 2017. Forming process using austempered ductile iron (ADI) in an automotive Pitman arm. The International Journal of Advanced Manufacturing Technology 91(1): 569-575.

Qi, X., Zhu, S., Ding, H. \& Xu, M. 2014. Theoretical and experimental analysis of electric contact surface hardening of ductile iron. Applied Surface Science 288: 591-598.

Sahasrabudhe, H., Soderlind, J. \& Bandyopadhyay, A. 2016. Laser processing of in situ TiN/Ti composite coating on titanium. Journal of the Mechanical Behavior of Biomedical Materials 53: 239-249.

Zhang, J., Zhang, N., Zhang, M., Lu, L., Zeng, D. \& Song, Q. 2014. Microstructure and mechanical properties of austempered ductile iron with different strength grades. Materials Letters 119: 47-50.

${ }^{a}$ Abdolali Fayyaz*

Department of Materials Engineering

Science and Research Branch

Islamic Azad University

Tehran, Iran.

bNasser Varahram and Parviz Davami

Department of Materials Science and Engineering Sharif University of Technology

Tehran, Iran.

*Corresponding author; E-mail: a.fayyaz@srbiau.ac.ir; abdolali.fayyaz@gmail.com

Received date : $3^{\text {rd }}$ July 2017

Accepted date : $13^{\text {th }}$ September 2017

In Press date : $16^{\text {th }}$ October 2017

Published date : $30^{\text {th }}$ October 2017 